\title{
Pesticides use in cocoa sector in Cameroon: characterization of supply source, nature of actives ingredients, fashion and reasons for their utilization
}

\author{
R. J. MAHOB ${ }^{1,2 *}$, M. NDOUMBÈ-NKENG ${ }^{2}$, G. M. TEN HOOPEN ${ }^{4}$, L. DIBOG ${ }^{2}$, \\ S. NYASSÉ ${ }^{2}$, M. RUTHERFORD ${ }^{3}$, M. MBENOUN ${ }^{2}$, R. BABIN $^{4}$, J. AMANG A $^{2}$ \\ $\mathrm{MBANG}^{2}, \mathrm{YEDE}^{1,2}$ and C.F. BILONG BILONG ${ }^{1}$ \\ ${ }^{1}$ University of Yaoundé I, Faculty of Sciences, P.O. (Box) 812 Yaoundé-Cameroon. \\ ${ }^{2}$ Institute of Agricultural Research for the Development, P.O. (Box) 2067 Yaoundé-Cameroon. \\ ${ }^{3}$ CABI Europe-UK, Bakeham Lane, Egham, TW209TY, UK. \\ ${ }^{4}$ CIRAD, UPR Bioagresseurs de cultures pérennes, Avenue Agropolis, TA A31/02, 34398 Montpellier Cedex 5, \\ France. \\ *Corresponding author; E-mail: raymondmahob@gmail.com; Tél.: (+237) $79187646 / 90304661$
}

\begin{abstract}
The chemical control is the widely control method applied in Cameroon for pests and diseases by all the cocoa producers without technical suitable assistance by the State as before 1980'S. However, it is known that farmers have less knowledge on the good pesticides use for the control of a specific pest. The objective of this study was to provide insight in current pesticide use in the cocoa sector in Cameroon. A stratified sampling scheme was used. A total of 251 cocoa farmers, 20 post-harvest cocoa traders and 37 chemical retailers were randomly selected and interviewed. The study showed that 35 different chemicals were marketed in Cameroon for use in cocoa: 4 herbicides, 11 fungicides and 20 insecticides. Of 251 farmers consulted, $96.8 \%$ said that they use pesticides on their farms while $3.2 \%$ did not. Fungicides were used most often by farmers $(61.8 \%)$ followed by insecticides (38.2\%). Eight active ingredients although, officially banned, were still being used on cocoa farms. Over $77 \%$ of farmers do not respect the official spray recommendations for chemicals. Moreover, $64 \%$ do not respect recommended doses. Two main pesticide-supply-pathways exist in Cameroon: a legal and illegal supply chain, which provides $51 \%$ of pesticides to cocoa farmers, resulting in an estimated loss of value added tax for the Cameroonian government of about 550000 to 2.4 million Euros per year. These results suggest that improved pests and diseases control by the State and raising farmer awareness about pesticide use in cocoa could greatly attribute to more sustainable cocoa economy in Cameroon.
\end{abstract}

(c) 2014 International Formulae Group. All rights reserved.

Keywords : Cocoa, pesticides, insecticides, fungicides, Cameroon.

\section{INTRODUCTION}

Introduced in Cameroon by the Germans in 1892 (Von Faber, 1907), cocoa (Theobroma cacao) is being cultivated by more than 400.000 farmers on at least 400.000 ha (Losch et al., 1992; ICCO, 2007; Jagoret,
2011). More recent yet so far unconfirmed data, suggest that the actual numbers are probably closer to 600.000 farmers and hectares. Annual production is around 200000 tons of cocoa beans and peaked in the 2012-2013 season at over 230.000 tons. 
However, production and revenues from cocoa could be substantially higher if the plant was not confronted with strong parasitic pressures, primarily diseases and insect pests. In Cameroon, the two main phytosanitary problems are black pod, caused by Phytophthora megakarya Brasier and Griffin, 1979 (Pythiales: Pythiaceae) and mirids, notably Sahlbergella singularis Haglund, 1895 (Hemiptera: Miridae) and Distantiella theobroma (Distant) (Hemiptera: Miridae). Phytopthora megakarya attacks cocoa pods while mirids cause severe damage to the cocoa canopy and can eventually even kill cocoa trees (Valet and Berry, 1997). In certain production zones, losses due to diseases can reach 70 to $100 \%$ when no control efforts are in place (Despreaux et al., 1988; NdoumbèNkeng, 2002; Ndoumbè-Nkeng et al., 2004). Mirid attacks can cause up to 30 to $40 \%$ of production loss, again when no control efforts exist. Accumulation of mirid-damage over several years can cause even higher losses (Entwistle, 1972; Collingwood, 1977; Lavabre, 1977; Sonwa et al., 2005). In order to reduce parasitic pressure to acceptable levels, farmers commonly use pesticides (Dormon, 2006; Tijani, 2006; Sonwa et al., 2008; Tadu et al., 2013). Although effective, pesticides are potentially harmful to human health and damaging to the environment. In Africa and particularly in Cameroon, the farmer and/or his family often apply pesticides without any precautions, mainly due to inadequate knowledge of the potential dangers of products being applied and a lack of personal protective equipment (PPE) (Matthews et al., 2003; Tijani, 2006; Matthews, 2008; Asogwa and Dongo, 2009). Pesticide residues in cocoa beans may also be harmful to consumers of cocoa products (Chan et al., 1995; Tijani, 2006; 2010; Asogwa and Dongo, 2009). In recognition of these concerns, the use of pesticides in many countries is strictly regulated. In the European Union (EU), the main importer of Cameroonian cocoa, new legislation entered into force in September 2008 with respect to pesticides authorised for use within Europe and maximum levels of pesticide residues (MRLs) permitted in food and feedstuffs, including imported commodities such as cocoa (ICCO, 2008).

Before and during the 1980's, production and commercialisation of cocoa beans in Cameroon was supervised by the State through the society for the development of cocoa (Société de Développement du Cacao, SODECAO). SODECAO granted subventions to cocoa farmers with the aim to stimulating the production of good quality cocoa beans. The State also provided technical assistance to farmers on the correct utilization of chemicals in cocoa orchards and controlled internal cocoa trade through the National Marketing Board for Commodities (l'Office National de Commercialisation des Produits de Base, ONCPB). Nowadays, these tasks are the responsibility of the National Office for Cacao and Coffee (Office National de Cacao et Café, ONCC) (Alary, 1996; Janin, 1996). The economic crisis at the beginning of the 1990s led the State to liberalise the cocoa sector, in particular the internal trade of pesticides. This involved the suppression of subventions allocated to farmers, and the ceasing of technical and pesticide assistance such as purchasing, distributing, and applying chemicals (Alary, 1996; Coulibaly et al., 2002; Sonwa et al., 2002, 2008). Abandoned by the State, the application of pesticides by farmers continued, but without the necessary knowledge and/or training to ensure proper use. This situation has continued until today. What is more, since no technical assistance is provided and stocks of older and previously banned pesticides still exist, there is a real risk that these are still used in cocoa production and trade.

Since the 1990s, no exhaustive studies focusing on pesticides used within the Cameroonian cocoa supply chain has been undertaken. In order to ensure the sustainable development of the cocoa sector in Cameroon and continued commercialization of cocoa, which necessitates cocoa without high levels of residue above MRLs stipulated by importing countries, the use of pesticides for 
cocoa in Cameroon should be monitored on a regular basis. For example, it is important to know whether prohibited substances are still being used, and if official spray recommendations are being applied.

The objective of this study was to obtain information on those pesticides, in terms of products and their active ingredients, being used in the cocoa production chain, how they are supplied and the reasons for their utilization.

\section{MATERIALS AND METHODS}

Study sites \& survey methodology

This study was carried out in 21 localities (Figure 1) in the Centre, South, Littoral and South-west Regions, as the major cocoa production areas in Cameroon (Alary, 1996; ICCO, 2007; Jagoret, 2011).

Field surveys focused on the three main stakeholder groups in the Cameroonian cocoa supply chain: farmers $(\mathrm{F})$, post-harvest traders (PT) and chemical retailers (CR). Farmers were consulted during the period 15 to 29 June, 2007, CR and PT during the period 8 19 January, 2008. A stratified sampling scheme was used and interviews were held, using a structured questionnaire, with a total of 308 individuals: $251 \mathrm{~F}, 37 \mathrm{CR}$ and $20 \mathrm{PT}$ (Table 1). The sampling repartition between the various study sites and cocoa stakeholders was based on the target populations' density, belonged to cocoa great basins, pesticide availability (chemicals with their notice and/or chemical wrappers) and easy access or presence to $\mathrm{CR}$ and $\mathrm{PT}$.

\section{Questionnaires}

The farmer questionnaire comprised two components: the first related to general information on the farmer and their farm, cocoa production and storage, the application of chemicals and information and training received on chemical use; the second related to information on individual chemicals, their manufacturer and supplier, why they are used and the manner in which they are used. This included details on the number of chemical applications per year, the use of pesticide mixtures (e.g. fungicide/insecticide) and the chemical formulation. Where possible, information on active ingredients, the supplier and the manufacturer of each chemical were also determined from labels on available chemical container(s). Those farmers not using pesticides were asked for the reason(s) why.

The PT questionnaire focussed on chemical treatment of beans. PT who confirmed that they undertook bean treatment were subsequently questioned about chemicals they used, their frequency of application and the method of application. The sources and extent to which they received information and training on proper chemical use were also determined. PT were consulted as to whether they were aware of the European Union regulations on pesticide use and maximum residue levels.

The CR questionnaire focussed on chemicals (e.g. insecticides, fungicides, herbicides, rodenticides, acaricides and mollucides) that they marketed for use in cocoa, whether they were officially registered to supply chemicals, the suppliers of their products and whether they provided or received information or training on proper chemical use. CR were also asked about the type of customers to whom they supplied chemicals for use on cocoa, and whether they or their organization were aware that new EU regulations concerning pesticide use and maximum residue levels were being introduced in Europe.

\section{Data analysis}

Data from the survey were manually processed and codified. Data were analyzed using univaried descriptive analysis. Application frequencies of pesticide applications were determined. Proportions were subjected to a Khi- 2 test at $P=0.05$ using SAS (version 9.1; SAS Institute, 1987). 


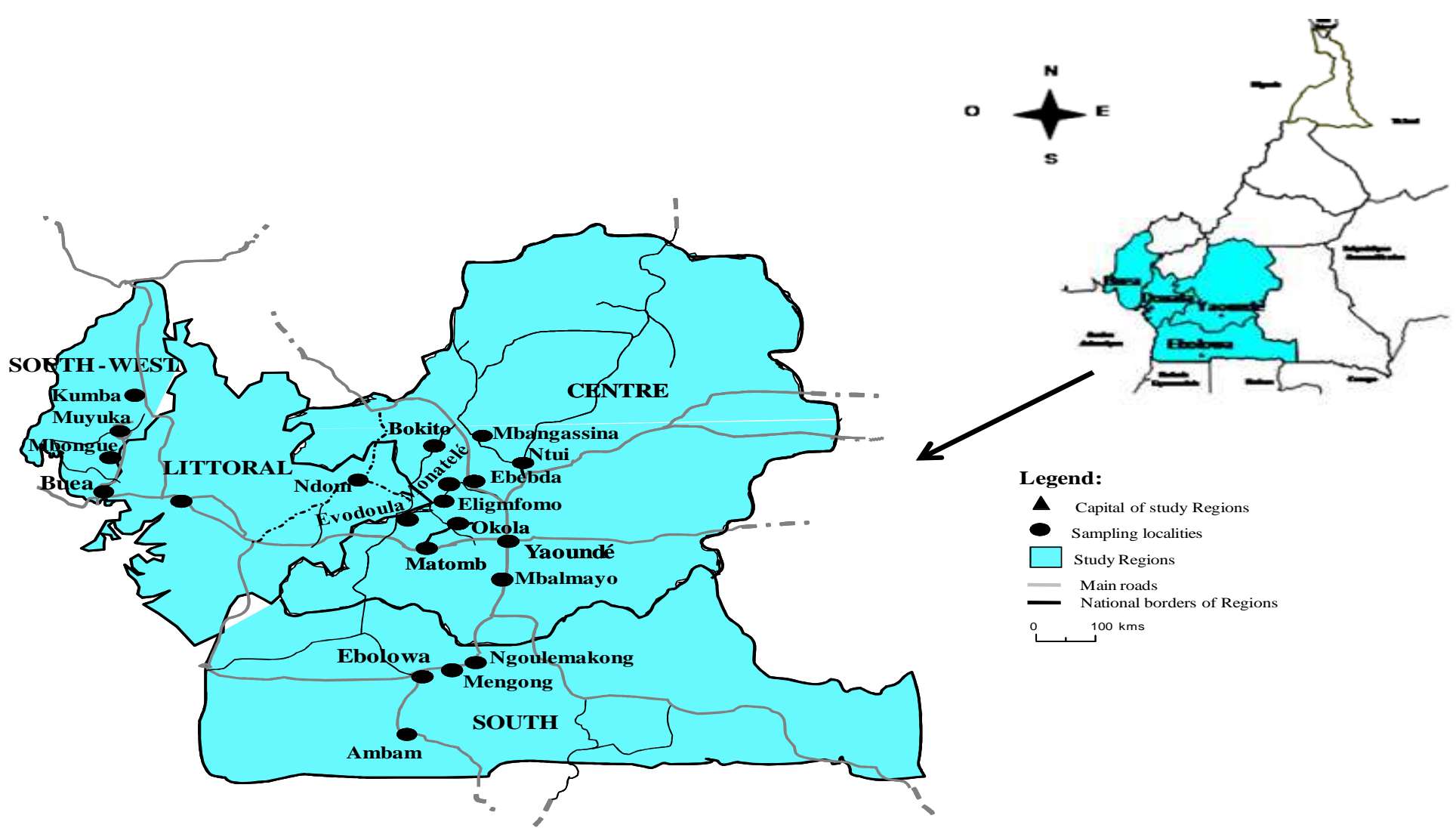

Figure 1: Geographical locations of our study sites (Regions and sampling localities), modified map of Cameroon (IRAD, 2009). 
Table 1: Sampling repartition for the four study sites.

\begin{tabular}{lcccc}
\hline Regions & \multicolumn{3}{c}{ Stakeholders } & Total \\
\cline { 2 - 4 } & Farmers & $\begin{array}{c}\text { Chemical } \\
\text { Retailers }\end{array}$ & $\begin{array}{c}\text { Post-harvest } \\
\text { cocoa traders }\end{array}$ \\
\hline Centre & 131 & 17 & 6 & 154 \\
South & 40 & 0 & 0 & 40 \\
Littoral & 30 & 12 & 4 & 46 \\
South-west & 50 & 8 & 10 & 68 \\
\hline Total & 251 & 37 & 20 & 308 \\
\hline
\end{tabular}

\section{RESULTS}

\section{Pesticide supply in Cameroon}

All products used in cocoa are imported. Figure 2 shows their respective country of origin, the main manufacturer (companies) and the manner by which they are distributed in Cameroon. Pesticides were imported primarily from France (30.9\%), Switzerland (14.0\%), Norway $(5.7 \%)$ and the USA $(5.1 \%)$. Other countries provided $16.6 \%$ while $27.7 \%$ were from unidentified origin. The main manufacturers were Casa Bernado Ltda (18.4\%), Arysta LifeScience (14.4\%) and Syngenta (9.3\%). Other companies provided $24.0 \%$, while the manufacturer could not be identified for $33.9 \%$ (Figure 2). Pesticides were imported by local companies and subsequently distributed to chemical retailers (95\% of all pesticides) or to farmer societies $(5 \%)$. Farmers obtained their pesticides either through chemical retailers or farmer societies. It was notable that $27.7 \%$ of all pesticide products were from unknown origin, while an even higher percentage $(39.9 \%)$ were from unknown manufacturer because the names of the companies were not available on the notice of the products consulted to check the information.

Although the post harvest traders obtain their pesticides exclusively through chemical retailers (Figure 2), not all suppliers confirmed that they were officially registered in Cameroon. Furthermore, the $27 \%$ who were not registered supplied $51 \%$ of all of the pesticides identified in the study (Figure 2).

A total of 28 different products are being marketed to cocoa farmers in Cameroon for use on their cocoa plantations (Table 2). These include two herbicides, 10 fungicides and 16 insecticides. The active ingredients of the herbicides were glyphosate and paraquat. The active ingredients of the fungicides were essentially copper compounds and metalaxyl while the insecticides comprised a broad range of different active ingredient(s).

\section{Pesticide use in Cameroon}

Of the 251 farmers consulted, 243 $(96.8 \%)$ used pesticides on their farms, while the rest $(n=8 ; 3.2 \%)$ did not, primarily due to a lack of financial resources when pesticides are needed. Out of the 243 farmers who used pesticides, $172(70.8 \%)$ were able to show some or all of the original chemical containers. The original packing allowed us to establish unequivocally the origin and manufacturer of the product. Although insecticides were the most varied class of pesticides, fungicides were most commonly used (Table 2). Fungicide formulations based on copper oxide together with metalaxyl/metalaxyl-M were used by all farmers who apply pesticides. Copper compounds solely, were used by 146 of farmers $(60.1 \%)$. Endosulfan was the most commonly used insecticide by far. Although 
forbidden since 2008 (See the list of pesticides not approved for use on cocoa by the Ministry of Agricultural and Rural Development through the ministerial regulation N71/08/MINADER/SG/DRCQ/SDRP/SRP/

of 17 July 2008 and the list of banned active substances for use on cocoa by the EU through regulation $\mathrm{N}^{\circ} 91 / 414 / \mathrm{EEC}$ of 10 June 2008<available from http//www.icco.org>), 55 farmers $(22.5 \%)$ continued to use endosulfan because of its efficacy. Eight of the active ingredients found to be used in Cameroon for the control of pests and diseases of cocoa, namely: benomyl, endosulfan, propoxur, methyl-parathion, fenobucarb, profenofos, cartap and diazinon are banned by both Cameroon and the EU.

Pesticides were for 95\% (231 out of 243 FR that use pesticides) applied using Side Lever Knapsack sprayers (SLKs) while only $5 \%$ (12 FR) of pesticides were applied using Motorised Mistblowers (MMs). Even though $112(46.0 \%)$ of FR asserted that they apply the recommended doses of pesticides, $71(29.1 \%)$ did not while 60 (24.9\%) FR stated not to have any knowledge on recommended doses. Application frequencies varied largely between farmers (Figure 3). In total, 136 $(56.2 \%)$ and $25(10.1 \%)$ of FR solely apply fungicides or insecticides, respectively while $82(33.7 \%)$ of FR applied both.

The mean number of annual insecticide and fungicide applications was $4.3 \pm 3.1$ and $6.9 \pm 4.8$, respectively. However, our study revealed that for insecticides, 136 of FR (56.2\%) did not apply any insecticides, 44 (18.0) \% of FR applied only once, 40 (16.3\%) twice, $7(2.8 \%) 3$ times, 9 (3.9\%) 4 times, 3 (1.1\%) 5 times and $4(1.7 \%)$ more than 5 times (Figure 3A). According to the farmers, $52(21.3 \%)$ applied fungicides molecules twice at most, $49(20.2 \%)$ applied Three to 5 times, $74(30.3 \%) 6$ to 8 times, $46(18.9 \%) 9$ to 11 times, $11(4.4 \%) 12$ to 14 times and 9 (3.5\%) 15 to 17 and $3(1.4 \%)$ more than 17 times (Figure 3B). The two principal reasons for using pesticides were to protect cocoa from black pod ( $67 \%$ of FR) or mirids $(30 \%$ of FR). Three percent of the farmers declared that they apply the chemicals either to stimulate production, to combat wilt, to obtain shining pods and/or to clean the tree trunk. Concerning chemical mixture (dosage), 87 $(36 \%)$ out of 243 farmers interviewed affirmed that they apply chemicals with respect to the recommended dose for chemicals used while $154(64 \%)$ do not respect.

\section{Cost of the mist pesticide management in Cameroon}

In Cameroon, the average cocoa farm is about 1 hectare. Average prices for a single dose of fungicide or insecticide (one dose for a 151 SLK sprayer) are around 1000 cfa. Approximately 15 to 25 tank loads of a 151 SLK sprayer are necessary to treat one hectare. This means that per hectare between 15,000 and 25,000 cfa are needed for a single treatment. The results of this study show that the mean application frequencies for fungicides and insecticides are 6.9 and 4.3, respectively. Given that $69.1 \%$ of farmers in Cameroon apply fungicides and $42.8 \%$ insecticides, and the cocoa farmer population is conservatively estimated at 400.000 farmers, this means that annually over 1.900.000 fungicide treatments take place and over 730.000 insecticide treatments. Since $51 \%$ of the pesticides come through unofficial channels this means that the Cameroonian government looses the $6.5 \%$ of values added taxes (VAT) on approximately 954.000 fungicide and 368.000 insecticide treatments. When the treatment of a hectare costs between 15.000 to $25.000 \mathrm{cfa}$, this means a loss of between 930 and over 1.550 million francs CFA for the fungicides and between 358 and 598 million francs CFA for the insecticides. In the current market, this would entail a loss of between 550 thousand and around 2.4 million Euros of revenues for the Cameroonian government per year. 


\section{Post- harvest cocoa traders}

Aluminium phosphide is applied to cocoa beans once a year by fumigation at the port of Douala in order to ensure bean conservation during transport. All post harvest cocoa traders interviewed asserted that they were knowledgeable with regard to
Cameroonian and EU regulations concerning the chemicals that are approved for use on cocoa. They were also aware that new regulations have been introduced in Europe with regard to the level of chemical residues permitted in imported cocoa.

Manufacturers (\% of their contribution of cocoa pesticides market)

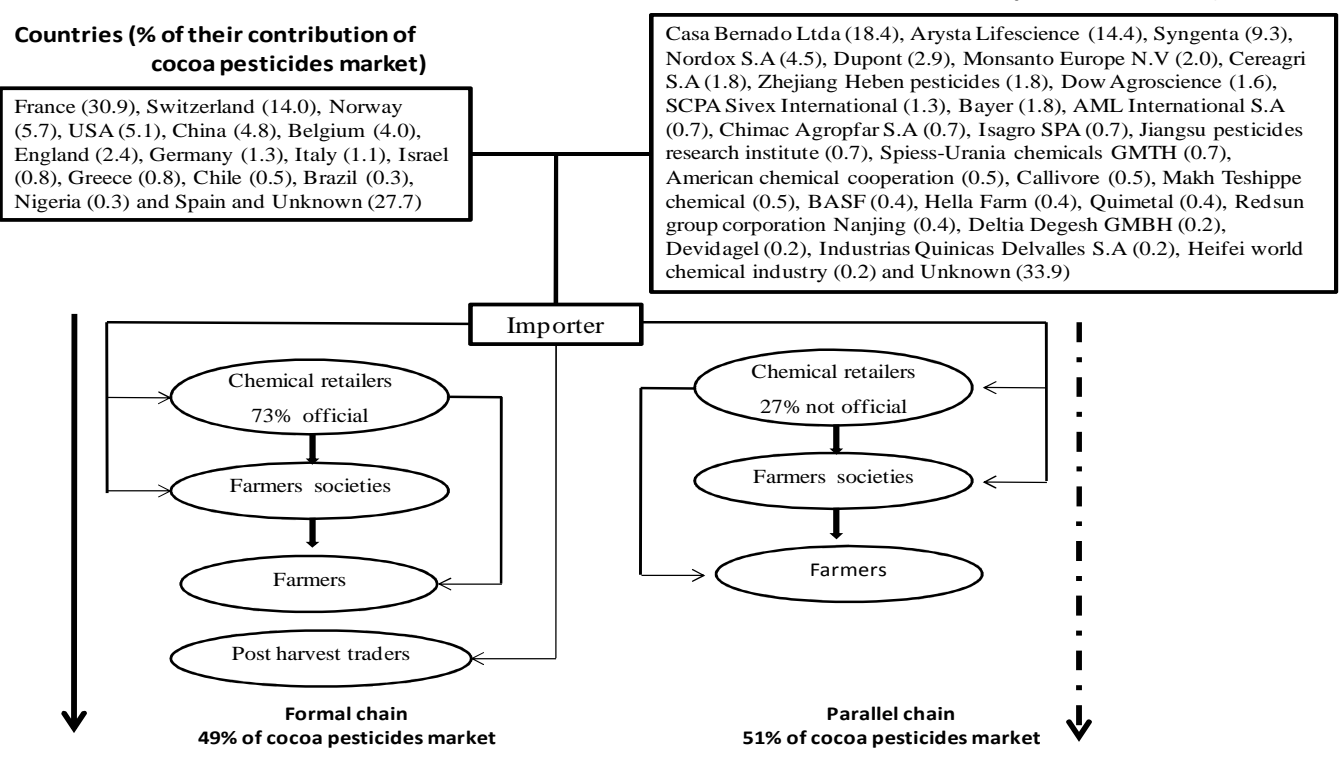

Legend:

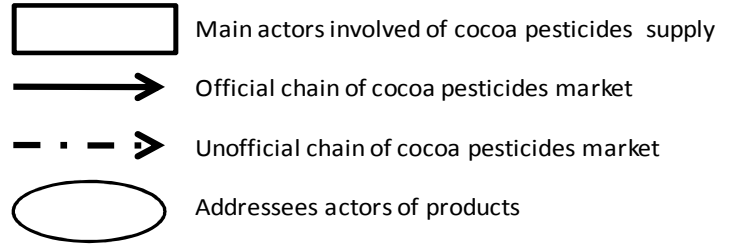

Figure 2: Characterization of pesticide supply chains in Cameroon followed with the relative contribution $(\%)$ for countries and main manufacturers. 
Table 2: Inventory of the different types of the chemicals being used on cocoa in Cameroon and their respective active ingredient (s), and comparison analysis of frequency of their farmers' farms application.

\begin{tabular}{|c|c|c|}
\hline \multirow[t]{2}{*}{ Name of pesticide } & \multirow[t]{2}{*}{ Active Ingredient } & \multirow{2}{*}{$\begin{array}{l}\text { Frequency }(\%) \text { of } \\
\text { crops treated per } \\
\text { year }(n=243)\end{array}$} \\
\hline & & \\
\hline \multirow{2}{*}{ Herbicides } & Glyphosate & --- \\
\hline & Paraquat & $-\cdots$ \\
\hline \multirow[t]{8}{*}{ Fungicides } & FR using Fungicides & $\underline{89.9(n=218)}$ \\
\hline & Copper oxide + Metalaxyl (Metalaxyl-M) & $71.4 \mathrm{a}$ \\
\hline & Cuprous/Hydroxide oxide & $60.1 \mathrm{a}$ \\
\hline & Metalaxyl + Mancozeb & $3.4 \mathrm{~b}$ \\
\hline & Maneb & $3.4 \mathrm{~b}$ \\
\hline & Mancozeb & $2.3 \mathrm{~b}$ \\
\hline & Benalaxyl + Copper oxide & $2.3 \mathrm{~b}$ \\
\hline & Benomyl $^{1}$ & $0.6 \mathrm{~b}$ \\
\hline \multirow[t]{21}{*}{ Insecticides } & FR using Insecticides & $43.8(n=106)$ \\
\hline & Endosulfan $^{1}$ & $22.5 \mathrm{a}$ \\
\hline & Cypermethrin & $7.3 \mathrm{~b}$ \\
\hline & Methyl parathion ${ }^{1}$ & $6.7 \mathrm{~b}$ \\
\hline & Imidacloprid & $5.6 \mathrm{~b}$ \\
\hline & Fenobucarb $^{1}$ & $4.5 \mathrm{~b}$ \\
\hline & Cartap $^{1}$ & $3.4 \mathrm{~b}$ \\
\hline & Chlorpyriphos (Chlorpyriphos-ethyl) & $3.4 \mathrm{~b}$ \\
\hline & Diazinon $^{1}$ & $3.4 \mathrm{~b}$ \\
\hline & Lambdacyhalothrin + Profenofos ${ }^{1}$ & $3.4 \mathrm{~b}$ \\
\hline & Cypermethrin + Profenofos ${ }^{1}$ & $2.3 \mathrm{~b}$ \\
\hline & Thiamethoxam & $2.3 \mathrm{~b}$ \\
\hline & Cypermethrin + Chlorpyriphos (Chlorpyriphos- & $2.3 \mathrm{~b}$ \\
\hline & ethyl) & $2.3 \mathrm{~b}$ \\
\hline & Cypermethrin + Dimethoate & $2.3 \mathrm{~b}$ \\
\hline & Cypermethrin + Imidacloprid & $0.6 \mathrm{~b}$ \\
\hline & Propoxur ${ }^{1}$ & ---- \\
\hline & Dimethoate & --- \\
\hline & Deltamethrin & --- \\
\hline & Malathion ${ }^{1}$ & ---- \\
\hline & Aluminium phosphide ${ }^{*}$ & \\
\hline
\end{tabular}

The values (percentage of farmers attesting to utilizing these molecules for application) followed with the same letter are not significantly different at a 5\% significance level comparison within pesticide class (fungicides and insecticides molecules respectively);

---- Active ingredient(s) not used by farmers but sold by chemicals retailers;

Active ingredient(s) approved for use in cocoa (See the list of homologated pesticides in Cameroon of 31 July 2013 , available from <http//www.minader.cm/uploads/File/Liste\%20des\%20Produits\%20homologu\%C3\%A\%20APV\%31\%20 JUILLET\%202013\%20Grd\%20Public\%20V1.pdf>);

${ }^{1}$ Active ingredient(s) banned on cocoa by Cameroon and UE (See the ICCO, 2008 and Bateman, 2008 lists of pesticides; available from<http//www.icco.org or http://www.cocoafederation.com/Manual_ICCO_2ndEd_final[1].pdf>).

*only used by post-harvest cocoa traders. 

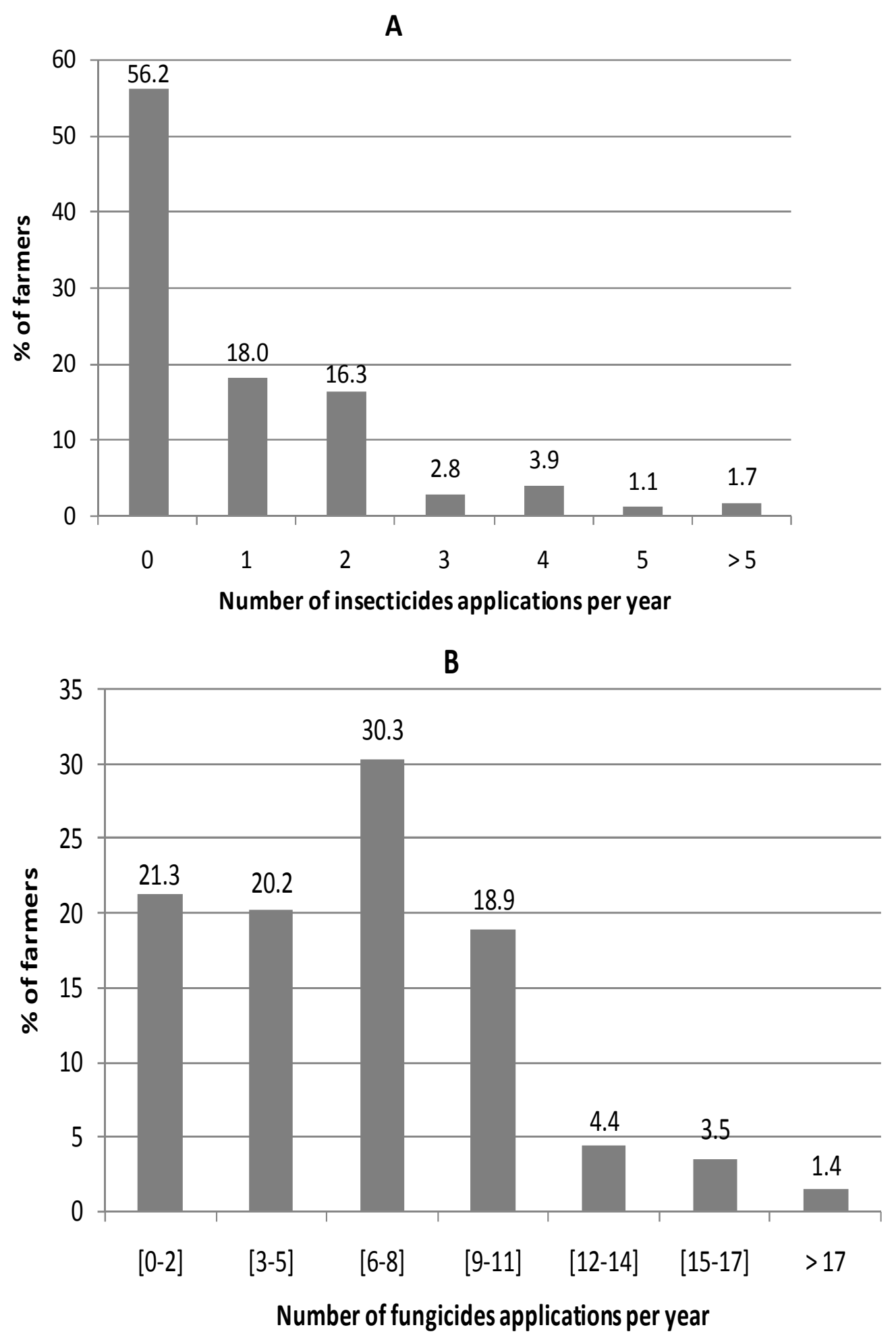

Figure 3: Annual farmer application frequency of A) insecticides and B) fungicides in Cameroon. 


\section{DISCUSSION}

In 1989, the Cameroonian institution (ONCB), which stabilised cocoa prices and provided subsidies and pesticides with the aid of bilateral and multilateral donors, was abolished (Sonwa et al., 2002). In the 1990's, under pressure of the international community to implement policies intended to restore the economic and financial balance of Cameroon, the Cameroonian government abandoned almost all "aid programs" for cocoa farmers. Now, cocoa farmers became themselves responsible for buying and applying pesticides on their farms. Despite economic hardships, almost $96.8 \%$ of the interviewed farmers apply pesticides on their farms. The most commonly used pesticides are: fungicides, for the control of black pod and insecticides, for mirid control. Out of 251 interviewed farmers, $168(67 \%)$ identified black pod and $75(30 \%)$ identified mirids as the most serious constraints to cocoa production in Cameroon. Previous research proves them right (e.g. Valet and Berry, 1997). It also shows that farmers are aware of these problems and that they try to control them.

The differences in application frequency between insecticides and fungicides are related to the official spray recommendations. For control of black pod, treatments should be effectuated every two to three weeks, depending on the fungicide used, contact or systemic, respectively, while insecticides are to be applied twice a year. This difference reflects the seriousness of the problem as well as the biology/epidemiology of the disease and biology/ecology of the pest. For example, Phytophthora pod rot, caused by Phytophthora megakarya, causes higher losses than mirids (Nyassé et al., 1999; Ndoumbè-Nkeng and Sache, 2003; NdoumbèNkeng et al., 2004). This is explained by the fact that a large part of Cameroonian cocoa plantations consist of agroforestry systems with a high level of shade, which creates unfavourable conditions for mirids yet favourable ones for black pod (Babin et al.,
2010). Yet, when looking in detail at the actual spray frequencies, we see that only a small part of the farmers who spray, 75 $(16.3 \%)$ and $57(23.3 \%)$ for insecticides and fungicides, respectively, seem to follow the official spray recommendations correctly (Figure 3). Four insecticide applications for mirid control are recommended. Two during the pullulating period between July and August, with a three week spacing between applications while the third and fourth applications, again spaced three weeks apart should take place at the end of the harvest season, thus somewhere between December and February. Between May to November 10 to 12 fungicide applications are recommended, depending on production zone and whether a contact or systemic fungicide is used. For contact fungicides fortnightly intervals, and for systemic three week intervals are recommended (Memento de l'Agronome, by Ministère des affaires étrangères, 2002). The actual number of farmers that follow spray recommendations correctly is probably even lower than presented here, since application timing is also essential. Yet, in this study, no information relative to timing was gathered. In addition, many farmers, over $50 \%$, did not respect recommended doses per SLK. On top of that, the use of banned active ingredient (s) (MINADER, 2008; 2013, ICCO, 2008) on cocoa farms (Table 2) also confirms that farmers seem to lack the information and/or training necessary for the proper use of pesticides on their cocoa farms. This situation is likely one of the consequences of the liberalisation of the cocoa sector in the early 1990s and particularly of the ensuing end of the technical assistance provided to farmers on the correct use of pesticides. Our findings support the previous several studies which reported that farmers and farm workers use chemicals in a hazardous way because they do not respect instructions and recommendations related to their adequate use (Sonwa et al., 2002, 2008; Dormon, 2006; Tijani, 2006; 
2010). This situation could continue to occur in our country despite the existence of the State regulation through a National Commission of the Pesticides Regulations because we observed (1) a low government intervention, and (2) most of the time, farmers do not know much about chemicals such as the choice and the respect of adequate ingredients, homologated in the country. For example, from our study, we noted that farmers don't know the annual list of approved pesticides for use in cocoa because it is not available at their level, according to the interviewed farmers' response. Thus, they asserted us that they always use the accustomed chemicals products or the available ones. We are aware that inside these pesticides, some ones are obsolete and other ones are banned for use on cocoa on the basis that the government and retailers of cocoa pesticides in Cameroon have in most cases not taken responsibility to provide training related to the proper use of pesticides for the cocoa farmers to enable them reach the end users with precautionary measures or respect of the regulation of their employment. According to the previous authors, this lack of information and/or formal training by farmers and farm workers about the homologated pesticides and their proper use of pesticides is one of the reasons why banned pesticides are still in use in Cameroon. To stop the use of these banned substances in cocoa production and to help avoid the major negative externalities their use engenders, health related, economic and environmental, it is essential that Ministry of Agriculture and Rural Development (MINADER) takes a leading role in raising farmer awareness and provides the information on the use of alternative pesticides.

Results show that a non-official pesticide supply chain provided $51 \%$ of the pesticides in use by cocoa farmers in Cameroon. Such a non-official supply chain, without official inspection explains the presence of unlabeled chemicals at farms which precludes basically their correct use. The macro-economic consequences are also non negligible. The cost of the mist pesticide management is another negative consequence of the liberalisation in Cameroon of the pesticide sector. Before the economic crisis in the early 1980s, the State ensured the purchasing, distributing and application of pesticides in cocoa agroforests. During this period, it was not possible that pesticides were provided through retailers that were not officially registered. As a result, no taxes were lost since the State regulated the cocoa sector and in particular the pesticides sector (trade and use). Alary (1996) and Janin (1996) noticed that the complete disengagement of the State in the cocoa sector has had negative consequences for the farmers because of their poor knowledge related to the nature of active ingredient approved for use on cocoa, their doses and application frequency and official costs of the pesticides.

The results show that several pesticides, especially herbicides and insecticides, although marketed for use by cocoa farmers are not used (Table 2). Over $80 \%$ of cocoa orchards in Cameroon have dense canopies. In consequence, these plantations have high levels of shade and the soils are covered by cocoa leafs and twigs and do not permit lots of undergrowth, precluding the use of herbicides. Another reason might be that manual removal of herbs is considered less costly than using herbicides although this is debatable since the use of herbicides as a longer lasting impact than manual removal of herbs. The lack of use some insecticides: Dimethoate, Deltamethrin, Malathion and Aluminium phosphide could be due to the fact that these products are not commonly marketed for insect and more specifically mirid control.

The results presented here clearly show that only a small portion of Cameroonian cocoa farmers apply pesticides in accordance with the recommendations. This entails an economic loss to the farmers as well as to the 
state. In order to improve farmer and state revenues through increased cocoa productions, it is essential that farmers receive adequate information and training on pesticide use. Several mechanisms though which such training could take place exist. For example, The Sustainable Tree Crops Program (STCP), which is managed in Cameroon conjointly by the International Institute of Tropical Agriculture (IITA) and MINADER, provides the Cameroonian cocoa sector with a framework for collaboration between farmers, the global cocoa industry, local private sector, national governments, NGOs, research institutes, and development investors. Within this framework, the STCP farmer field schools (FFS) could be even more extensively exploited to aid the cocoa farmers with respect to pesticides use. In this way, the Cameroonian cocoa sector can attribute even more to the sustainable development of the Cameroonian economy.

\section{ACKNOWLEDGEMENTS}

The authors acknowledge the European Cocoa Association (ECA) for providing financial support for this study. Special recognition is extended to all participating farmers, chemical retailers and post harvest cocoa traders for their collaboration.

\section{REFERENCES}

Alary V. 1996. Libéralisation de la filière cacaoyère : vue et vécue par les planteurs du Cameroun. Rev. Rég. Dévelop., 4 : 1 24.

Asogwa EU, Dongo LN. 2009. Problems Associated with Pesticide Usage and Application in Nigeria Cocoa Production: A Review. Afric. J. Agr. Res., 4(8): 675683.

Babin R, Ten Hoopen GM, Cilas C, Enjalric F, Yede, Gendre P, Lumaret JP. 2010. Impact of shade on the spatial distribution of Sahlbergella singularis Hag. (Hemiptera: Miridae) in traditional cocoa agroforests. Agr. Forest Entomol., 12: 6979.

Bateman R. 2008. Pesticide use in cocoa. $1^{\text {st }}$ Edition, a guide for training, administrative and research staff, p.57.

Chan MH, Kim C, Khoday K, Receveur O, Kuhnlein HV. 1995. Assessment of dietary exposure to trace metals in Baffin Inuit food. Environ. Health Persp., 103(7-8): 740-746.

Collingwood CA. 1977. Mirides africains associés aux cacaoyers. In Les Mirides $d u$ Cacaoyer, Lavabre EM (ed). Maisonneuve et Larose: Paris, France; 77-83.

Coulibaly O, Mbila D, Sonwa DJ, AkinAdesina, Bakala J. 2002. Responding to economic crisis in sub-Saharan Africa: New farmer-developed pest management strategies in cocoa-based plantations in Cameroun. Integrat. Pest Manag Rev., 7: 165-172.

Conacher HBS, Mes J. 1993. Assessment of human exposure to chemical contaminants in foods. Food Add. Contam., 10(1): 5-15.

Despreaux D, Cambrony D, Clément D, Nyassé S, Partiot M. 1988. Study of cocoa black pod diseases in Cameroon: definition of new fight strategies. Proceeding of $10^{\text {th }}$ International Cocoa Research Conference at $\mathrm{S}^{\mathrm{t}}$ Domigue, Dominicain Republic; 407-412.

Dormon ENA. 2006. From a technology focus to innovation development: The management of cocoa pests and diseases in Ghana. Doctorate thesis, Wageningen University, Netherlands; 44-48.

Entwistle PF. 1972. Pests of cocoa. Entwistle PF (ed). Longman Group Ltd: London, UK; p.779.

ICCO. 2007. Rapport de la commission consultative sur l'économie cacaoyère mondiale à Accra au Ghana. Mesures prises par les gouvernements pour parvenir à une économie cacaoyère plus durable : cas du Cameroun, p8. Available 
from: <http://www.icco.org/pdf/ Government/7\%20-20Mr.\%20Michael $\% 20$ Ndoping.pdf $>$. Last accessed $27^{\text {th }}$ of Febuary 2013.

ICCO. 2008. La réglementation de l'Union Européenne sur les pesticides à usage agricole sur cacaoyer. Available from: <http://www.icco.org/pdf/An_report>. Last accessed $28^{\text {th }}$ of August 2013.

IRAD. 2009. Institute of Agricultural Research for Development: Agroecological zones delimited. Available from: <http://www.iradcameroon.org/carte_us.php $>$ Last accessed $24^{\text {th }}$ of October 2013.

Janin P. 1996. Un planteur sans Etat peut-il encore être un planteur? Polit. Afric., 62: 45-56.

Jagoret P. 2011. Analyse et évaluation de systèmes agroforestiers complexes sur le long terme : Application aux systèmes de culture à base de cacaoyer au Centre Cameroun. Thèse de Doctorat de l'Université de Montpellier SupAgro, Département Systèmes Intégrés en Biologie, Agronomie, Géosciences, Hydrosciences et Environnement, France, Montpellier, p.288.

Lavabre EM. 1977. Les Mirides du Cacaoyer. Ed., G.-P. Maisonneuve et Larose : France, Paris, p.366.

Losch B, Daviron B, Freud C, Gergely M. 1992. Relance régionalisée de la production paysanne de cacao et de café au Cameroun. Phase I. Cadrage général de la relance. MINAGRI/CIRAD/ SOFRECO Vol. 2, p.21.

Mariau D. 1996. Lutte intégrée contre les ravageurs des cultures pérennes tropicales. CIRAD, p.196.

Matthews GA, Wiles T, Baleguel P. 2003. A survey of pesticide application in Cameroon. Crop Prot., 22: 707-714.

Matthews GA. 2008. Attitudes and behaviours regarding use of crop protection products-A survey of more than 8500 smallholders in 26 countries. Crop Prot., 27(5): 834-846.

Memento de l'Agronome. 2002. $5^{\text {ème }}$ édition. Cirad, GRET, Ministère français des affaires étrangères. Paris, France, p.1691.

MINADER. 2013. Liste des pesticides homologués au Cameroun. Liste réservée au Grand public, p.40. Available from $<$ http//www.minader.cm/uploads/File/List e\%20des\%20Produits\%20homologu\%C3 \%A\%20APV\%31\%20JUILLET\%202013 $\%$ 20Grd\%20Public\%20V1.pdf $>$ ).

MINADER. 2008. Arrêté No71/08/D/ MINADER/SG/DRCQ/SDRP/SRP,

portant interdiction d'utilisation de certains pesticides sur cacao tels amitraz, carbaryl, cartap, diazinon, endosulfan, fenobucarb, méthyl-parathion et propoxur. Direction des Programmes Agricoles : Yaoundé, Cameroun.

Ndoumbè-Nkeng M, Sache I. 2003. Lutte contre la pourriture brune des cabosses du cacaoyer au Cameroun. Phytoma. Déf. Végét., 562: 26-32.

Ndoumbè-Nkeng $M$, Cilas C, Nyemb E, Nyasse S, Bieysse D, Flori A, Sache I. 2004. Impact of removing diseased pods on cocoa black pod caused by Phytophthora megakarya and on cocoa production in Cameroon. Crop Prot., 23: 415-424.

Ndoumbè-Nkeng M. 2002. Incidence des facteurs agro-écologiques sur l'épidémiologie de la pourriture brune des fruits du cacaoyer au Cameroun: contribution à la mise en place d'un modèle d'avertissements agricoles. Thèse de doctorat, Institut National Agronomique, France, Paris-Grignon, p.151.

Nyassé S, Grivet L, Risterucci AM, Blaha G, Berry D, Lanaud C, Despréaux D. 1999. Diversity of Phytophthora megakarya in Central and West Africa revealed by isozyme and RAPD markers. Mycol. Res., 103: $1225-1234$. 
SAS Institute. 1987. SAS User's Guide: Statistics Version 9.1.3. SAS Institute: Cary, NC.

Sonwa DJ, Coulibaly O, Adesina AA, Weise SF, Tchatat M. 2002. Integrated pest management in cocoa agraforests in Southern Cameroon: Constraints and overview. Integrat Pest Manag Rev., 17: 191-199.

Sonwa DJ, Weise SF, Adesina AA, Nkongmeneck AB, Tchatat $\mathrm{M}$, Ndoye $\mathrm{O}$. 2005. Production constraints in cocoa agroforestry in West and Central Africa: the need for integrated pest management and multi-institutional approaches. The Forest. Chron., 81(3): 345-348.

Sonwa DJ, Coulibaly O, Weise SF, Janssens MJJ. 2008. Management constraints of cocoa agroforest during acquisition and application of pesticides in humid forest zone of Cameroon. Crop Prot., 27(8): 1159-1164.

Tadu Z, Djiéto-Lordon C, Babin R, Yede, Messop-Youbi EB, Fomena A. 2013.
Influence of insecticide treatment on ant diversity in tropical agroforestry system: Some aspect of the recolonization process. Int. J. Biodivers. Conserv., 5(12): 832-844.

Tijani, A. A. 2010. Factors influencing pesticide use among cocoa farmers in Ondo State, Nigeria. Second RUFORUM Biennial Meeting 20-24 September 2010, Entebbe, Uganda; 361-364.

Tijani AA. 2006. Pesticides use practices and safety issues: The case of cocoa farmers in Ondo State, Nigeria. J. Human Ecol., 19(3): 183-190.

Varlet F, Berry D. 1997. Réhabilitation de la protection phytosanitaire des cacaoyers et caféiers du Cameroun. Tome I. rapport principal; Tome II : annexes. Douala, Cameroun, Conseil interprofessionnel du cacao et du café; 202-204.

Von Faber FC. 1907. Bericht über die pflanzenpathologische expedition nach Kamerun. Der Tropen., 11: 735-775. 